This is a peer-reviewed, accepted author manuscript of the following research chapter: Gillies, L. (2012).

Determining the applicable law for breach of competition claims in the Rome II regulation and the need for effective consumer collective redress. In J. Devenney, \& M. Kenny (Eds.), European Consumer Protection: Theory and Practice (pp. 257-281). Cambridge: Cambridge University Press.

https://doi.org/10.1017/CBO9781139003452.017

\title{
'Determining the Applicable Law for Breach of Competition Claims in the Rome II Regulation and the Need for Effective Consumer Collective Redress'
}

\section{ABSTRACT}

\section{Lorna Gillies *}

The Communitarisation of choice of law rules for non-contractual obligations is the most recent illustration of Treaty objectives in promoting the compatibility of choice of law and jurisdiction rules between the Member States. On 11 January 2009, with the exception of Denmark, Regulation No 864/2007 on the Law Applicable to NonContractual Obligations (hereafter the Rome II Regulation) came into force across the Community. The Regulation provides freedom for the parties to select the applicable law governing a 'non-contractual obligation' that falls within the scope of the Regulation. In addition to the general choice of law rule, the Regulation also provides specific choice of law rules for torts and delicts arising out of (inter alia) unfair competition and acts restricting free competition. The aim of these rules is to determine the applicable law for consumers or their representatives to claim damages for breach of Articles 101 and 102 TFEU (ex Articles 81 and 82) as a result of crossborder anti-competitive business activities. More recently, the European Commission has also released a Green Paper on Collective Consumer Redress (COM (2008) 794 Final) which proposes a Community collective redress mechanism to operate between the Member States for the resolution of consumers' claims. After briefly outlining the general approach of the Rome II Regulation, the paper explores the specific choice of law rules for the torts of unfair competition under Article 6(1) and acts restricting competition under Article 6(3). Having identified the key concepts and challenges that may arise for consumers and their representatives with the application of these new applicable law rules, the paper will consider to what extent the proposed EU Consumer Collective Redress mechanism could further enhance the ability of consumers to claim damages against businesses that undertake anti-competitive practices in breach of Article 101 or 102 TFEU (ex Article 81 or 82 EC) to the detriment of consumers.

\footnotetext{
* Dr Lorna Gillies, School of Law, University of Leicester. Email lorna.e.gillies@leicester.ac.uk. This paper is dedicated to Rachael.
} 


\section{INTRODUCTION}

The last five years have witnessed a decrease in the parallelism between EU competition and consumer law policies. Recent policy and legislative developments in these politically distinct areas of EU law highlight that effective consumer protection and redress - where it does not currently exist at the level of Member States - will increasingly rely upon effective regulation or enforcement of anti-competitive business practices via EU competition law. ${ }^{1}$ Indeed Recital 7 of Regulation EC 1/2003 requires Member States to ensure that private individuals can pursue private redress mechanisms via national courts. Consequently, the increasing prevalence of private enforcement - namely private claims for damages - as a means of regulating market activity and enhancing consumer protection between the Member States necessitates reference to Community rules on private international law. ${ }^{2}$ In 2002 , Withers commented that the "cause of action [for a claim in tort for breach of competition law] is very much at an incipient stage of development.' 3 The same could be said for analogous rules of private international law. Indeed, at the time Withers' valuable analysis of jurisdiction and applicable law rules alluded to the need for many other significant 'additional procedural and evidential issues' 4 to be addressed to ensure the effectiveness of private enforcement as a remedy for victims of anti-competitive behaviour. Nevertheless, in accordance with Treaty obligations, the EC has continued to implement measures designed to facilitate private enforcement of competition laws. Furthermore it has also continued to implement measures pursuant to judicial cooperation in civil and commercial matters. ${ }^{5}$ The most recent development connecting both measures is Regulation EC 864/2007 on the Law Applicable to Non-Contractual Obligations ${ }^{6}$ (hereafter the Rome II Regulation)

\footnotetext{
${ }^{1}$ For example, Regulation 1/2003 on the Implementation of the Rules on Competition Laid Down in Articles 81 and 82 of the Treaty, 16 December 2002, OJ 2002 L1/1 (04.01.2003).

${ }^{2} \mathrm{C}$. Withers, 'Jurisdiction and applicable law in antitrust tort claims', (May) Journal of Business Law (2002) 250 ; B. Rodger, 'Private enforcement and the Enterprise Act: an exemplary system of awarding damages?' 24(3) European Competition Law Review (2003) 103, pp.103-104 ; D. Fairgreave and G. Howells, 'Collective Redress Procedures - European Debates', 58(2) International and Comparative Law Quarterly (2009) 379, p.381.

${ }^{3}$ Withers, note 2 ibid. Words added for syntax.

${ }^{4}$ Withers, note 2 ibid, p. 255 ; see further in response Rodger, note 2 ibid.

${ }^{5}$ Article 81 (ex Article 65), TFEU.

6 'Regulation EC 864/2007 on the Law Applicable to Non-Contractual Obligations,' (hereafter the 'Rome II Regulation') OJ 2007 L199/40.
} 
which provides rules to determine the applicable law of a non-contractual obligation. A key development offered by this new, communitarised private international law instrument is contained in Article 6. Article 6 of the Rome II Regulation determines the applicable law that will apply when private, final consumers or their representatives claim damages against businesses for anti-competitive practices or acts which have restricted competition, thereby impeding consumer choice.

The protection afforded to consumers by EU competition law can be distinguished by the duty owed to consumers, ${ }^{7}$ the nature of the enforcement mechanism pursued (public or private), the type of the remedy sought (predominantly injunctions) and the location of the parties (whether domiciled or situated in the same or different jurisdictions). In general throughout the EU, public enforcement has been a - if not 'the'- prevalent redress mechanism, whether by way of proceedings pursued by the Commission ${ }^{8}$ or by the individual Member States themselves. On the other hand, private enforcement of competition law has traditionally been limited to injunctive relief. ${ }^{9}$ Such a remedy is premised on objective of deterring businesses from acting in an anti-competitive manner either against their competitors or to protect private, enduser consumers. ${ }^{10}$ Breach of either Articles 101 or 102 TFEU ${ }^{11}$ (ex Articles 81 or 82 EC) also permits such victims of anti-competitive behaviour to claim damages. Whilst the ability to claim damages will invariably also deter businesses contemplating anticompetitive practices, the purpose of damages in such instances is to provide 'victims' (essentially businesses or consumers) with compensation. ${ }^{12}$ As far as private, final consumers are concerned, the ability to claim damages should provide

\footnotetext{
7 Whether owed by the Member State or a business operating in the market.

8 J. Fitchen, 'Choice of Law in International Claims Based on Restrictions of Competition: Article 6(3) of the Rome II Regulation', 5(2) Journal of Private International Law (2009) 337 at p.338. See also specifically on Article 6(3), Elena Rodriguez Pineau, 'Conflict of Laws Comes to the Rescue of Competition Law: the New Rome II Regulation', 5(2) Journal of Private International Law (2009) 311.

9 'Regulation EC 2006/2004 of the European Parliament and of the Council of 27 October 2004 on Cooperation Between National Authorities Responsible for The Enforcement of Consumer Protection Laws (The Regulation On Consumer Protection Cooperation)', OJ 2004 L364/1 ; C.A. Jones, Private Enforcement of Antitrust Law, (OUP, 1999).

${ }^{10}$ For example, the recent codified 'Directive 2009/22/EC on Injunctions for the Protection of Consumers' Interests,' OJ 2009 L110/30.

${ }^{11}$ Both numberings will be provided.

${ }^{12}$ It is acknowledged that the definition of victim is developing as this area of law develops: see further on this Fitchen, note 8 supra.
} 
them with increased protection against unscrupulous businesses and the effect of their commercial activities on the marketplace. ${ }^{13}$

First, it is necessary to consider what constitutes anti-competitive behaviour or business structures that have a detrimental effect on consumers in the marketplace. At this stage, it is worthy to clarify the meaning of consumer. The prohibitions against anti-competitive behaviour or abuse of a dominant position in Articles 101 and 102 TFEU (ex Articles 81 and 82 EC) traditionally applied to 'any user.' 14 The Articles in the most recent version of the Treaty refer in the majority to the effect of anticompetitive behaviour upon 'trading parties.' 15 Consumers are referred to in the context of such behaviour being permissible when it would be deemed to be 'fair' 16 to them, for example by improving competition and reducing prices. However, for the purposes of this paper, it is necessary to focus on the protection to be given to the consumers in the 'restricted' ${ }^{17}$ sense. The restricted meaning of consumer applies in other recently enacted Community rules of private international law, including Article 15 of the Brussels I Regulation (on jurisdiction in civil and commercial matters) and Article 6 of the Rome I Regulation (on the law applicable to contractual obligations). In accordance with Recital 21 of the Rome II Regulation, 'the conflict-of-law rule should protect competitors, consumers and the general public ...' 18 The Rome II Regulation therefore distinguishes between other competitor businesses and consumers as private individuals (as well as the market as a whole). It would be fair to say that economic behaviour either horizontally between competitors or vertically between suppliers and competitors 'damage(s) [...] the consumer interest' ${ }^{19}$ as a result of price fixing arrangements / cartels which have the effect of limiting production in the marketplace 'to the prejudice of the consumer' ${ }^{20}$ or ancillary conditions being imposed in contracts with consumers (for example, requiring consumers to enter into insurance or warranty agreements for the purchase of

\footnotetext{
${ }^{13}$ Withers, note 2 supra, p. 271.

${ }^{14}$ G. Howells and S. Weatherill, Consumer Protection Law, $2^{\text {nd }}$ ed, (Ashgate, 2005), p.533.

15 Article 101(1) TFEU.

${ }^{16}$ Article 101(3) TFEU (ex Article 81(3)).

${ }^{17}$ C-89/91 Shearson Lehmann Hutton v TVB [1993] ECR 1-139.

${ }^{18}$ Rome II Regulation, Recital 21. Itallics added for emphasis. The French language version refers to 'consommateurs.'

${ }^{19}$ Howells and Weatherill, note 14 supra, p.528. Words modified and removed for syntax.

${ }^{20}$ Article 82 EC, observed by Howells and Weatherill as a 'rare explicit reference [in the Treaty] to the position of the consumer'; ibid, pp.549-50. Words added for syntax.
} 
particular goods). Consumers may also be adversely affected by economic structures imposed by business activities such as monopolies and mergers. Such activities may constitute unfair commercial practices against consumers in the marketplace. Second, it is necessary to consider where the parties are territorially located in order to determine the extent of business liability for breach of competition laws. The location of the parties is significant as far as competition law is concerned for, as Withers reminds us, '(E)ach [...] legal system [...] establishes a regime for the protection of effective competition [...] within their territorial jurisdiction.' ${ }^{21}$ In accordance with Courage, such regimes are at the behest of 'safeguarding [individual] rights' ${ }^{22}$ under EU competition law. Depending on where the parties are located, consumers may be exposed to anti-competitive behaviour either in the same Member State as the business or between Member States. It is the latter situation which this paper is concerned. As technology continues to identify new consumer markets and competitors located in different Member States (and indeed beyond), the EU has recognised that the potential for cross-border anti-competitive practices has increased. EU competition policy aims to provide a coherent and consistent approach to the regulation of business activities and enforcement of competition laws for businesses operating in markets within and between the Member States. Until recent initiatives for the review of the consumer acquis, ${ }^{23}$ the same could not be said for consumer protection policy in the EU. The 'maximisation' ${ }^{24}$ of consumer protection policy is now being pursued via proposals for, inter alia, a draft Directive on Consumer Rights $^{25}$ and an EU Consumer Collective Redress mechanism. ${ }^{26}$ When infringements of competition laws occur, different methods of enforcement or redress can be pursued depending on the nature of the breach and the location of the victims affected. As Jones attests, clearly defined communitarised rules of private international law and appropriate redress mechanisms will be required to facilitate

\footnotetext{
${ }^{21}$ Withers, note 2 ibid. Words removed for syntax.

${ }^{22}$ C-453/99 Courage v Crehan [2001] ECR I-6297; [2002] QB 502, p.522, 29E. Word added for syntax.

${ }^{23}$ European Commission, 'Green Paper on the Review of the Consumer Acquis', COM (2006) 744.

${ }^{24}$ Hans W. Micklitz and Norbert Reich, 'Crónica De Una Muerte Anunciada: The Commission Proposal for a Directive on Consumer Rights', 46(2) Common Market Law Review (2009) 471.

${ }^{25}$ European Parliament and Council, 'Proposal for a Directive on Consumers Rights', COM (2008) 614 final 2008/0196 (COD).

${ }^{26}$ Green Paper on Consumer Collective Redress COM (2008) 794 Final 27/11/08.
} 
private enforcement as an additional means of redress for breach of competition laws. ${ }^{27}$

Whilst encapsulated in the Treaty, private enforcement of competition law has not traditionally been recognised and relied upon as an available (or implicitly preferred) option for resolving disputes in comparison to the established rules for anti-trust claims in the United States. ${ }^{28}$ However in order to safeguard the interests of other businesses, competitors and ultimately final consumers in the European marketplace, parties who have suffered loss or damage as a result of anti-competitive behaviour should be able to utilise (at least in theory) private means of redress via the ability to claim damages. In essence, the right is facilitated by the Treaty but the application is dependent, given the infancy of competition law, ${ }^{29}$ upon measures ${ }^{30}$ implemented by the Member States. For example, in the United Kingdom, the Enterprise Act 2002 permits consumer representatives raise bring proceedings on behalf of consumers to the Competition Appeals Tribunal. ${ }^{31}$ However, when parties are domiciled or located in different Member States, or the defendant's actions result in damage to the plaintiff who is situated in another jurisdiction, we have to turn to the rules of private international law ${ }^{32}$ to determine three key elements. First - assuming the nature of the claim and the consumer has title to sue ${ }^{33}$ - where can the aggrieved party sue (lex fori)? Second, once the lex fori has been established, what laws (lex cause) will apply? Finally, once a judgment has been obtained from the court, how and where can that judgment be recognised and enforced? ${ }^{34}$ This paper is concerned with recent developments in relation to the second matter - namely Community rules determining the applicable law - in the context of private redress for anti-competitive behaviour

\footnotetext{
${ }^{27}$ Jones, note 9 supra, pp. 88-9, 91-2.

${ }^{28}$ On which see Jones, note 9 supra, p.16 and generally; Withers, note 2 ibid, p.250, 254 et seq;

Rodger note 2 ibid, p.103 et seq; Fitchen, note 8 supra, p.338.

${ }^{29}$ Fitchen, note 8 supra, p.340.

${ }^{30}$ Including measures for consumer collective redress: see Fairgreave and Howells, note 2 supra.

${ }^{31}$ Enterprise Act 2002 Part 8.

${ }^{32}$ Acknowledged by Fitchen, note 8 supra who then focuses his analysis of Article 6(3) of Rome II on examination on the identity of the victim and the operation of current national remedies in his analysis of Article 6(3).

${ }^{33}$ Akin to instituting proceedings for an injunction against a business; H. W. Micklitz, N. Reich, P. Rott, Understanding EU Consumer Law, (Intersentia/Hart, Oxford, 2009), p.356.

${ }^{34}$ In the private international law/conflict of laws sense, the term 'enforcement' is distinct from the 'enforcement' of (substantive) competition laws. The former is concerned with rules that permit enforcement of a judgment from the court of a Member State (or third state) in the courts of another Member State.
} 
that has caused damage ${ }^{35}$ to private, final (end-user) consumers. The new Rome II Regulation seeks to facilitate cross-border private enforcement of competition laws by stipulating the rules that will determine the applicable law for such claims. In seeking to make a (focussed) contribution to the on-going debate on this complex and contentious topic, this paper considers the private international law perspective by examining the intrinsic value of EU communitarised applicable law rules for noncontractual obligations. The particular focus of this paper is whether - in the context of the private enforcement of/claim for a breach of competition laws when a dispute occurs between consumers and businesses situated in different jurisdictions - the combination of the applicable law rules in the new Rome II Regulation and the proposals for an EU Collective Consumer Redress mechanism can together provide a coherent basis for consumers and their representatives to seek damages for anticompetitive practices.

A number of the key issues and terms in the Rome II Regulation will be considered to highlight the practical challenges that consumers and their representatives will be required to assess before raising proceedings in the courts of a Member State. Whilst the rules may, in theory at least, deter businesses from participating in cross-border anti-competitive practices, in practice, the consensus is that the content ${ }^{36}$ and current lack of guidance on interpreting these new ${ }^{37}$ applicable law rules will render it even more difficult for consumers and their representatives to pursue claims for damages as a means of private enforcement of competition laws. The effective application of Article 6 could therefore hinge upon either current collective procedures for private enforcement operating in the Member States (where they already exist) ${ }^{38}$ or the proposed EU-led Consumer Collective Redress Mechanism (if and when it applies, and the form it will take). ${ }^{39}$ What must be remembered is that despite justified concerns vis-a-vis the content and current limitations on the interpretation of Article 6 of Rome II, the (possibly indirect) deterrent ${ }^{40}$ effect of these rules may prevent or

\footnotetext{
${ }^{35}$ cf Article 15, Rome II, on which see M. Danov, 'Awarding exemplary (or punitive) antitrust damages in EC competition cases with an international element - the Rome II Regulation and the Commission's White Paper on Damages', European Competition Law Review 29(7) (2008) 430.

${ }^{36}$ On which see generally A. Dickinson, The Rome II Regulation: The Law Applicable to NonContractual Obligations, (OUP, 2008), Chapter 6.

${ }^{37}$ As far as English conflict of laws is concerned.

${ }^{38}$ Rodger, note 2 supra.

${ }^{39}$ Fitchen, note 8 supra, p.338.

${ }^{40}$ Micklitz, Reich and Rott, note 33 supra, p.382.
} 
facilitate the resolution of disputes without resorting to court proceedings, thereby improving competitive relations between businesses operating amongst the Member States for the benefit of all parties and the specifically the protection of consumers. ${ }^{41}$

\section{GOING BEYOND COURAGE: ARTICLE 101 AND 102 TFEU AND THE COLLECTIVE CONSUMER INTEREST}

According to Howells and Weatherill '(C)onsumer policy is a concealed aspect of competition policy and vice versa[.]' ${ }^{42}$ The enforcement of competition law operates at a number of levels, all of which in theory should be open to a private consumer to utilise. ${ }^{43}$ At an institutional level, the Commission's role in ensuring effective investigation of suspected infringements of competition law was affirmed in Francesconi ${ }^{44}$ and BEUC v Commission. ${ }^{45}$ As Micklitz, Reich and Rott confirm

[...] the powers have shifted. The Community may be authorised to order Community-wide measures and it may be required to comply with the duties to protect consumer's health and safety as set out in Articles 153, 95 and 30 EC. The Commission becomes increasingly more competent; however, it exposes itself to the risk of becoming subject to liability claims. ${ }^{46}$

The Court of First Instance in Guerin Automobiles v Commission ${ }^{47}$ permitted a complaint by an undertaking (Guerin) that 'had suffered damage as a result of restrictive practices [to] rely ... on the rights conferred on it by Articles [81 and 82] ... which produce direct effects in relations between individuals.' ${ }^{48}$ The emphasis appears to rest on the exclusivity of power vested in the Commission to investigate such allegations. ${ }^{49}$ At Member State level, the principles of equivalence and effectiveness place obligations upon Member States to ensure that Community competition rules and remedies (in particular damages ${ }^{50}$ ) are implemented for the benefit and protection of participants in the EU marketplace. Failure to do so risks the prospect of proceedings by private parties. Ever since Courage $v$ Crehan $^{51}$ and

\footnotetext{
${ }^{41}$ Micklitz, Reich and Rott, ibid.

${ }^{42}$ Howells and Weatherill, note 14 supra, p.519. Punctuation modified for syntax.

${ }^{43}$ Howells and Weatherill, ibid, p.535.

${ }^{44}$ C326/86 Francesconi [1989] ECR 2087.

45 T-37/92 BEUC v Commission [1994] ECR II-285.

${ }^{46}$ Micklitz, Reich and Rott, note 33 supra, p.340.

${ }^{47}$ C282/95 Guerin Automobiles v Commission

${ }^{48}$ Guerin Automobiles, ibid at p.39; Jones, note 9 supra, p.78, words modified for syntax.

49 T38/96 Guerin Automobiles v Commission [1997] E.C.R. II-1223 at para 25 et seq.

${ }^{50}$ See further Dahnov, note 35 supra; Fitchen, note 8 supra.

${ }^{51}$ Courage, note 22 supra.
} 
Henkel $^{52}$ there has been a specific ability (ie. right) of businesses to be able to claim damages as a result of a breach of Article 101 or 102 TFEU (ex Article 81 or 82). The call is illustrative of the triple objective of competition law in protecting the marketplace, protecting competitor's interests and protecting competitors.

More recently, the Commission's White Paper on Actions for Damages for Breach of Anti-Trust Rules ${ }^{53}$ proposes that businesses should be able to seek damages against competitors for breaches of competition law. Such remedies now extend to consumers. As Mickiltz Reich and Rott attest, Member States must ensure that they enact and implement EU laws to protect consumers or they will be liable for either a failure to act or a failure to properly implement measures ${ }^{54}$ and would therefore, as Withers confirms, be in breach of their statutory duty under the European Communities Act 1972. In terms of how competition law 'protects' consumers, the distinction can be made to some extent between substantive law and procedure. As Jones affirms, ' $[\ldots]$ the Community provides the substantive right and the national court provides the procedural means of safeguarding that right in the absence of Community legislation.' 55 In accordance with the objectives of Regulation 1/2003 referred to earlier, it has always been the duty of Member States' national laws to 'protect $[\ldots]$ Community rights under competition rules $[\ldots]$ it is incumbent upon the Member States to provide remedies and procedures suitable for the protection of those rights.' 56 The starting point for any claim for anti-competitive behaviour is Articles 101 and 102 (ex Articles 81 and 82 EC). According to Jones,

Articles [81 and 82] create directly effective Community rights, and the right to damages is a necessary corollary of the principle of direct effect. The right of reparation arises equally with respect to loss and damage caused by private parties breaching Community law as it does from Member States breaching Community law. ${ }^{57}$

As a means of regulating the market and compensating victims of anti-competitive behaviour, there is clear justification for enabling competitors to pursue private damages claims against one another. Not surprisingly, however, there has been very

\footnotetext{
${ }_{52}$ C-167/00 Verein für Konsumenteninformation v Karl Heinz Henkel OJ C192, 08/07/2000, 11.

53 "Article $82 \mathrm{EC}$ and the White Paper on 'Actions for breach of the EC anti-trust rules', COM (2008) 165.

${ }^{54}$ Micklitz, Reich, Rott, note 33 supra, p.321, 325 ; Withers, note 2 supra, p.252.

${ }_{55}^{55}$ Jones, note 9 supra, p.61, words italicised for emphasis.

${ }^{56}$ Articles 3 and 11, Regulation EC 1/2003 ; Jones, ibid, p.60.

${ }^{57}$ Jones, ibid, p.78.
} 
limited quantitative evidence as to the ability and success of businesses claiming such damages via the courts. A recent study undertaken by Rodger of the position of private enforcement in the United Kingdom concluded that such actions (if they arise) tend to be resolved or settle out of court. ${ }^{58}$ As far as consumers are concerned, two questions follow. First, to what extent can consumers benefit from equivalent protection? Second, following Wither's query of the need for a 'Euro tort,' 59 to what extent it is necessary to have communitarised applicable law rules for such disputes? In respect of the first question the ability of consumers, in theory, to claim damages against businesses should improve market conditions, deter businesses from contemplating 'unfair commercial practices' and increase protection for consumers. In practice, it is a moot point to what extent the general take-up of private enforcement of claims for breach of competition will be by individual consumers - even less so when their dispute involves a business located in another Member State. It is submitted that the effectiveness of such protection provided by competition law could depend upon the enhancing the collective interest of consumers via an EU Collective Consumer Redress mechanism. Such mechanisms currently operate to some extent across the Member States. ${ }^{60}$ However, as a consequence of the principles of subsidiarity and proportionality, the approach is neither widespread nor consistent. ${ }^{61}$ The potential for cross-border disputes between consumers and businesses as a result of anti-competitive behaviour renders both the applicable law rules governing such disputes and consequently the practical ability of consumers to raise such proceedings more acute. Therefore as regards the second question, a communitarised approach seeks to ensure that consumers in the Member States are provided with consistent, maximised protection against businesses operating in other Member States whilst at the same time the compatibility of jurisdiction and choice of law rules continue to be implemented in accordance with Treaty obligations. ${ }^{62}$ Nevertheless, doubts have justifiably been raised regarding the basis and terms of Article 6 of the Rome II Regulation and - as is the invariable nature of communitarised private international

\footnotetext{
${ }^{58}$ B. Rodger, 'Private Enforcement of Competition Law, The Hidden Story: Competition Litigation Settlements in the United Kingdom, 2000-2005', 29(2) European Competition Law Review (2008) 96116, p.97.

${ }^{59}$ Withers, note 2 supra at $\mathrm{p} .253$.

${ }^{60}$ See Fairgreave and Howells, note 2 supra.

${ }^{61}$ Micklitz, Reich and Rott, note 33 supra, p.350, 361-2.

${ }^{62}$ Article 81 TFEU (ex Article 65).
} 
law rules - a lack of current guidance from either the Commission or the European Court of Justice in defining the key provisions contained in Article $6 .{ }^{63}$

Accordingly the rest of this paper is structured as follows. The next part will consider how Article 6 determines the applicable law of a non-contractual obligation in a claim for damages by consumers or their representatives. The specific aspects of Rome II that need to be addressed by the European Court of Justice will be highlighted. The third part will consider collective redress traditionally, in terms of the Consumer Policy Strategy and the Treaty. The fourth and final part will consider the treaty basis and competence for the EU Consumer Collective Redress mechanism of the type proposed for consumers. The paper will conclude by considering to what extent such a proposal can assist in the practical application of Article 6 of the Rome II Regulation.

\section{THE TORT OF UNFAIR COMPETITION AND THE POSITION OF ENGLISH PRIVATE INTERNATIONAL LAW, THEN AND NOW}

As the next section of this paper will consider, over the course of its inception and recent enactment, commentators including Dickinson and Fitchen have justifiably questioned the utility of the connecting factors in Article 6 in the Rome II Regulation with scepticism. Such views are meritorious. There is a certain novelty, as far as private international law is concerned, with applicable law rules for torts of this kind. English law has never had specific (in the sense of distinct) choice of law rules per se for anti-competitive behaviour or acts restricting competition. Therefore, it is worthwhile to briefly review how unfair competition previously constituted a tort for the purposes of private international law. Both jurisdiction and choice of law rules will be briefly considered as the latter is dependent upon the effective classification by the forum. The classification of what constitutes a tort for the purposes of private international law is dependent significantly upon first which forum has jurisdiction over the dispute and second the approach taken by the forum in classifying the tort in

\footnotetext{
${ }^{63}$ Dickinson, note 36 supra and Fitchen, note 8 supra.
} 
question. ${ }^{64}$ It is worthy to remember that the process of classification must be undertaken by the forum, ${ }^{65}$ meaning that the 'cause of action' must have been capable of being recognised as a tort in itself ${ }^{66}$ by the forum for the 'purposes of private international law.' 67

It is necessary to determine where the defendant is situated before the English courts can assume jurisdiction, either via the 'traditional rules' or the 'Brussels I Regime'. The outcome is the same - if the English court has jurisdiction, English law will apply as the lex fori to any claim for damages as a result of a tort. If the defendant business is not situated in a Member State, Section IV of the Rules of Civil Procedure, Part B, Paragraph 6.36(9) ${ }^{68}$ applies where '(a) damage was sustained in within the jurisdiction; or (b) the damage sustained resulted from an act committed within the jurisdiction.' It is possible for the defendant business to argue that England is not the most appropriate forum on the grounds of forum non conveniens and that the English court should decline jurisdiction in favour of another more appropriate forum. ${ }^{69}$ If the defendant business is situated in a Member State, the 'Brussels I Regime' applies. Following its predecessor the Brussels Convention 1968, Regulation 44/2001 EC, 70 (hereafter the Brussels I Regulation) requires that if the defendant business is not sued in the court of the Member State where it is situated (by virtue of Articles 2 and 60), then it can only be sued in the courts of another Member State by virtue of one of the grounds of special jurisdiction in Article 5. Article 5(3) of the Brussels Convention $1968^{71}$ provided that a claim in tort could be brought in the courts of the place where the tort, delict or quasi-delict occurred. ${ }^{72}$ In line with the objectives of that

\footnotetext{
${ }^{64}$ P.M. North and J.J. Fawcett, Cheshire and North's Private International Law, $13^{\text {th }}$ ed, (Butterworths, 1999), p.618 et seq referring to the Private International Law (Miscellaneous Provisions) Act 1995 which has now been superceded by the Rome II Regulation.

${ }^{65}$ Dicey, Morris and Collins, The Conflict of Laws, $14^{\text {th }}$ ed, (Sweet and Maxwell, 2006), p.1904.

${ }^{66}$ North and Fawcett, note 64 supra.

${ }^{67}$ North and Fawcett, ibid and at p.629 vis. the Private International Law (Miscellaneous Provisions) Act ; Dicey, note 65, p.1095-1906. Words italicised for emphasis.

${ }^{68}$ Previously Paragraph 6.20(8) CPR.

${ }^{69}$ Withers, note 2 ibid, p. 259.

70 'Regulation (EC) No 44/2001 of 22 December 2000 on jurisdiction and the recognition and enforcement of judgements in civil and commercial matters', 2001 OJ L12/1 (hereafter the 'Brussels 1 Regulation').

71 'Convention on Jurisdiction and Recognition and Enforcement of Judgments in Civil and Commercial Matters', 1978 OJ L304 (the Brussels Convention 1968).

${ }^{72}$ Unlike the Brussels I Regulation, it did not at that stage, apply to 'threatened wrongs' ; North and Fawcett, note 64 supra, p.215.
} 
Convention, ${ }^{73}$ an autonomous, Community ${ }^{74}$ meaning was given to the definition of a tort. There is authority from Garden Cottage Foods v Milk Marketing Board ${ }^{75}$ in support that a claim for unfair competition constitutes the "equivalent" 76 of a tort for the purposes of ascertaining jurisdiction under Article 5(3) of the Brussels Convention (and thereby its successor the Brussels I Regulation). The focus of the Brussels I Regulation in allocating jurisdiction is therefore on the place where the harmful event, or the act of unfair competition occurred, or may occur. This is significant as far as unfair competition is concerned for it will determine the territorial location of the market (or indeed part of the market), being the place where the consumer or competitor sustained damage, which justifies the allocation of special jurisdiction as an alternative to the defendant's domicile. In the English case Provimi Ltd v Avensis Animal Nutrition $S A,{ }^{77}$ the English High Court upheld a claim in tort for damages for breach of competition law under Article 5(3) of the Brussels Convention despite the existence of a jurisdiction clause in the contract between manufacturers, sellers and purchasers of vitamin tablets. Similar provisions in the Lugano Convention ${ }^{78}$ were also considered in the Norwegian case Saba Molnlycke AS v Proctor and Gamble Scandinavia Inc. ${ }^{79}$ In Saba, a case involving the alleged misleading advertising of nappies, the Norwegian Court of Appeal held that damage could include "nonphysical" ${ }^{80}$ damage such as unfair - or as the court termed it "improper or disloyal" 81 - competition irrespective of where the defendant company was situated. More recently, the English High Court held that as no damage had accrued in England, the English court could not take jurisdiction under Article 5(3) of the Brussels I Regulation. The court in SanDisk Corp referred to earlier authority from the European

\footnotetext{
${ }^{73}$ LTU v Eurocontrol C29/76 [1976] ECR 1541.

${ }^{74}$ Kalfelis v Schroeder C189/87 [1988] ECR 5565.

${ }^{75}$ Garden Cottage Foods v Milk Marketing Board [1984] AC 130 ; see also North and Fawcett, note 64 supra, p.621 (despite the authors' acknowledgement that the Law Commission's 1984 Working Paper did not think it was clear whether unfair competition would be classified as tortuous ; ibid).

${ }^{76}$ North and Fawcett, ibid.

${ }^{77}$ Provimi Ltd v Avensis Animal Nutrition SA [2003] EWCH 961 (Comm).

${ }^{78}$ A parallel Convention to the 1968 Convention which operates between EFTA states ; the Convention on Jurisdiction and the Enforcement of Judgments in Civil and Commercial Matters, done at Lugano, 16 December 1988 (the Lugano Convention), OJ 1988 L319/9. The most recent version can be found at OJ 2007 L339/3.

${ }^{79}$ Saba Molnlycke AS v Proctor and Gamble Scandinavia Inc [1997] I L Pr 704 ; J.J. Fawcett and J.M. Carruthers, Cheshire, North and Fawcett Private International Law, $14^{\text {th }}$ ed, (OUP, 2007), p.247.

${ }^{80}$ Saba Molnlycke $A S$, ibid, p.709.

${ }^{81}$ Saba Molnlycke $A S$, ibid.
} 
Court of Justice in Dumez France SA v Hessische Landesbank ${ }^{82}$ and the English High Court in Domicrest v Swiss Bank Corp. ${ }^{83}$ which both held that the place where the damage originates forms the basis of a claim under Article 5(3) of the Brussels Convention. In this respect, Withers' assessment of the 'place where the harmful event occurred' and his analogy with the ECJ's reasoning in Shevill v Press Alliance 84 are instructive. Withers is correct in his view that it is the place where the anticompetitive behaviour de facto occurred that establishes jurisdiction as opposed to the place where any illicit agreement was entered into or adverse economic consequences occurred. ${ }^{85}$ Withers considered how the place where an agreement to undertake anticompetitive behaviour is colluded between competitors can often be a distinct place (or territory) from the place where the anti-competitive behaviour actually occurred. Furthermore, the anti-competitive behaviour alleged can occur in multiple jurisdictions - reflecting market conditions - a concern echoed by Dickinson and Fitchen in their assessments of Article 6 of the Rome II Regulation. Relying on Shevill - as Withers does 'by analogy' ${ }^{86}$ - opens up the possibility for consumers to sue either where the business is situated or in the courts of the place where the harmful event occurred. However, the consequence of this approach is the fragmentation, or 'Mosaikbetrachtung, ${ }^{87}$ of claims in different jurisdictions and the increased expense to consumers and their representatives in pursuing claims for damages in multiple jurisdictions.

Similar concerns have been echoed regarding classification and location of the tort for the purposes of ascertaining the applicable law. Prior to the Rome II Regulation, the applicable law rules for the majority of cross-border torts (excluding defamation) were to be found in the Private International Law (Miscellaneous Provisions) Act 1995, sections 11 (as the general rule) and 12 (as the exception). Under Section 11 of the 1995 Act, the applicable law was the law of the place where the tort occurred

\footnotetext{
${ }^{82}$ Dumez France SA v Hessische Landesbank (220/88) [1990] E.C.R. I-49 - most recently considered in a dispute alleging loss by unfair means of a licensing agreement in Future Investments $S A \mathrm{v}$ Federation Internationale de Football Association [2010] EWHC 1019 (Ch).

${ }^{83}$ Domicrest v Swiss Bank Corp [1999] QB 548.

${ }^{84}$ Shevill v Press Alliance SA C-68/93 [1995] ECR I-415.

${ }^{85}$ Withers, note 2 ibid, p. 261.

${ }^{86}$ Withers, ibid.

${ }^{87}$ See further on this Fitchen, note 8 supra.
} 
(whether in a single country (s.11(1)) or in different countries (s.11(2) ${ }^{88}$ ). Section 11(2)(c) applied 'the law of the country in which the most significant element or elements of those events occurred' to economic torts, including those 'unknown to English law.' ${ }^{89}$ The concern as to how an English court was to consider the approach of a foreign law in classifying such a tort has not necessarily been removed by the introduction of Article 6 of Rome II. Furthermore, in the absence of guidance from the ECJ, it may be some time before the connecting factors in Articles 6(1) and (3) can be interpreted with certainty.

\section{THE ROME II REGULATION}

The Communitarisation of choice of law rules for non-contractual obligations is the most recent illustration of Treaty objectives ${ }^{90}$ for "promoting the compatibility of the rules applicable in the Member States concerning the conflicts of laws and of jurisdiction.' ${ }^{91}$ On 11 January 2009, Regulation 864/2007 on the Law Applicable to Non-Contractual Obligations (hereafter the Rome II Regulation) came into force across the Community (with the exception of Denmark). The Rome II Regulation provides freedom for the parties to select the applicable law governing a "noncontractual obligation' that falls within the scope of the Regulation. However, such freedom is excluded from claims made under Article 6. ${ }^{92}$ Stone regarded the Rome II Regulation proposal as a welcome development in regulating the "three-dimensional function of competition law ... in a modern conflict-of-laws instrument.' 93

Recital (6) of the Rome II Regulation states that '(T)he proper functioning of the internal market creates a need, in order to improve the predictability of the outcome of litigation, certainty as to the law applicable and the free movement of judgments, for the conflict-of-law rules in the Member States to designate the same national law

\footnotetext{
${ }^{88}$ Section 11(2)(c) for 'economic' torts such as unfair competition.

${ }^{89}$ Cheshire and North, note 64 supra, p.637.

${ }^{90}$ Articles 61 and 65(b) EC.

${ }^{91}$ Recital 2, Rome II Regulation.

92 By virtue of Article 6(4). Dickinson helpfully suggests that Article 14 might still be able to apply in situations involving a specific competitor (ie by virtue of Article 6(2) and Article 4) ; note 36 supra, p.426. The European Court of Justice's approach to Articles 6(2) and (4) is awaited.

${ }^{93}$ P. Stone, EU Private International Law, (Edward Elgar, 2006), p.365.
} 
irrespective of the Member State in which the claim is brought.' 94 In general, Article 3 specifies that the Rome II Regulation has universal application which means that it applies regardless of the situation giving rise to the non-contractual obligation (the example given earlier about the place where the illicit agreement took place) and the obligation itself has any connection with an EU Member State. However, as will be seen with the specific rule for competition law, there has to have been an infringing act in the Member State, for example an act restricting competition in Article 6(3). This means there is no need for a party to be domiciled or resident in an EU Member State, the only connection for jurisdiction deemed necessary is that the dispute can be tried in a court of an EU Member State, which as we have seen could be either under Article 2 or Article 5 of the Brussels I Regulation. ${ }^{95}$

The Rome II Regulation applies to situations involving 'a conflict of laws, to noncontractual obligations in civil and commercial matters.' In determining what constitutes a conflict of laws (a dispute with a foreign element), the Rome II Regulation is to be given an autonomous interpretation. Under English law, foreign law must be pleaded and proved by the party wishing to rely on it. ${ }^{96}$ The European Court of Justice is authorised to give Preliminary Rulings on the interpretation of acts of the EU and, akin to the Brussels I Regulation and Rome I Regulation, this extends to Preliminary Rulings on the Rome II Regulation. The English courts must therefore act in accordance with either decisions from or principles set down by the European Court of Justice. One of the key concepts is the meaning of 'non-contractual obligations.' 97 Before determining the applicable law under the Rome II Regulation, as we have seen briefly with jurisdiction, it is first necessary to characterise or classify the legal nature of the dispute according to whether the non-contractual obligation alleged to have been breached is as a result of a breach of a tort, unjust enrichment, negotiorum gestio or culpa in contrahendo. Each Member State has its own definition

\footnotetext{
${ }^{94}$ Recital 6, Rome II Regulation.

${ }^{95}$ Or alternatively, if there is more than one defendant, Article 6.

${ }^{96}$ A challenge highlighted by Dickinson (note 36 supra, pp.418-426) when applying more than one applicable law under Article 6(3) of the Rome II Regulation.

${ }^{97}$ If there was concurrent liability in contract and tort, it would be classified as a contractual liability; a point applied in the jurisdictional context in Source v TUV [1998] QB 54. However, according to Cheshire and North the better approach, despite the recent introduction of the Regulation and no authority in support, is that a tortuous classification is applied when operating the Regulation since "The Regulation envisages that there can be a tortuous obligation in the situation where the parties have a pre-existing contractual relationship and there can be a tortuous obligation to which there is a contractual defence," ; Fawcett and Carutthers, note 79 supra, p.779.
} 
of what constitutes a non-contractual obligation and it is therefore unfortunate that Recital 11 the Regulation offers limited guidance. Obligations that are noncontractual, and otherwise not excluded in Article 1(2), are to be defined in a positive way in the same way as Article 5(3) of the Brussels 1 Regulation. Like Article 5(3) of the Brussels 1 Regulation, the Rome II Regulation also applies to threatened wrongs. Damage is defined under Article 2(1) as 'any consequence arising out of a tort/delict ...' It has been suggested by Cheshire and North that this should be taken as direct damage, following a consistent approach with the Brussels 1 Regulation. 98 Furthermore, earlier concerns about what constitutes 'damage' 99 have - to some extent - been removed by Article 15 of the Rome II Regulation which determines, inter alia, the substance and procedural aspects of a non-contractual obligation including the basis of liability, grounds for exemption of liability, the assessment of damages and the remedy claimed. Danov maintains that irrespective of Article 15 the effect of both Recital 32 and Article 21 may render invalid any claim for punitive or exemplary damages applicable under the lex loci delicti that would be incompatible with the public interest of the forum. ${ }^{100}$ Whilst the desire to ensure consistency and predictability via the applicable law will not be at the cost of offending the public policy of the forum, public policy is likely to be rarely invoked.

Recital 14 of the Rome II Regulation states that the connecting factors contained in the Regulation "are the most appropriate to achieve (the) objectives of legal certainty and justice in individual cases." ${ }^{101}$ It is these connecting factors that are crucial in determining the basis upon which Articles 4 and 6 operate and, indeed, interact with each other.

\section{ARTICLE 4 - THE GENERAL APPLICABLE LAW RULE}

The general choice of law rule in the Regulation is provided in Article 4. Article 4 is designed to protect the individual party in a dispute where a non-contractual

\footnotetext{
${ }^{98}$ Fawcett and Carutthers, ibid, pp.797-798. Cf Dickinson, note 36 supra, p.397-398 who suggests that that the concept of damage under Article 6(1) and 6(3) is distinct from Article 5(3) of Regulation 44/2001 (the Brussels I Regulation) and, depending on the interpretation of Recital 21, could lead to an inconsistent application of jurisdiction and applicable law rules in determining whether damage has occurred in an unfair competition case.

99 See further Danov, note 35 supra.

${ }^{100}$ Danov, ibid, p.432 et seq.

${ }^{101}$ Words modified and added for syntax.
} 
obligation has been breached. It contains a general choice of law principle, an exception to that general principle and an escape clause, as follows. Article 4(1) states that the applicable law is the law of the country where the damage occurred. As with jurisdiction rules, the emphasis is to establish the lex causae of a territorial unit. Furthermore, the lex causae is not the law of the place where the indirect consequences of damage are felt. It is necessary therefore to determine the lex loci delicti commissi - specifically the lex damni - the place where the damage occurs, which can often be different to the place in which the event giving rise to the damage occurred. The exception is to be found in Article 4(2) which applies to 'internal' disputes, that is where both parties have the same habitual residence ${ }^{102}$ when the dispute arises, that law will apply. The 'escape clause' is provided by Article 4(3) which requires a manifestly more closely connected country to be established for its laws to apply instead. Like Article 4(5) of the Rome Convention 1980, Article 4(3) is intended to take into account the law that reflects the 'centre of gravity' of the dispute. The 'high threshold' 103 required for the application of Article 4(3) was recently considered, and specifically rejected, by the English High Court in Jacobs v MIB. ${ }^{104}$

\section{ARTICLE 6 - THE LAW APPLICABLE TO UNFAIR COMPETITION AND ACTS RESTRICTING COMPETITION}

Dickinson reminds us of the Commission's position on Article 6(1) and (2) when states that the 'act of unfair competition, the defendant's conduct must have some impact upon relations between the participants in a particular market, whether horizontally (between competitors) or vertically (as against consumers collectively).' ${ }^{105}$ When considering Article 6, it is useful to take as a starting point Recital 13 which states that, '(U)niform rules applied irrespective of the law they designate may avert the risk of distortions of competition between Community litigants' ${ }^{106}$ and Recital 19 which provides that '(S)pecific rules should be laid down for special torts/delicts where the general rule does not allow a reasonable balance to

\footnotetext{
102 The Regulation omits a definition of where a business is located for the same purpose.

${ }^{103}$ Fawcett and Carutthers, note 79 supra, p.799.

104 Jacobs v Motor Insurers Bureau [2010] EWHC 231 (QB).

${ }^{105}$ Dickinson, note 36 supra, p.403

${ }^{106}$ Recital 13, Rome II Regulation.
} 
be struck between the interests at stake.' ${ }^{107}$ The Commission commented on the draft Regulation to the effect that Article 6 was designed to

correspond to the victim's expectations, since the rule generally designates the law governing their economic environment. But it also secures equal treatment for all operators on the same market. The purpose of competition law is to protect a market; it pursues a macro-economic objective. ${ }^{108}$

As Dickinson has observed vis-à-vis Recital 21, 'the special rule in Article 6 is not an exception to the general rule in Article 4(1) but rather a clarification of it.' ${ }^{109}$ The dual purpose of the 'effects test' ${ }^{110}$ approach used to determine the applicable law rules for unfair competition is a 'market-orientated' ${ }^{111}$ choice of law rule designed to provide protection for 'competitors, consumers and the general public' 112 and facilitate the proper economic functioning of the EU market. Dickinson maintains however that the net effect is that the applicable law rules in Article 6 are 'sufficiently independent of the general rule for torts to be characterized as special rules in their own right.' 113 Indeed, this would reflect the aim of the Regulation to provide a 'flexible framework of conflict-of-laws rules [and] to enable the court seized to treat individual cases in an appropriate manner.' 114 With the aims of the Regulation and Recital 14 in mind, Article 6 provides the following choice of law rules. ${ }^{115}$

1. (T)he law applicable to a non-contractual obligation arising out of an act of unfair competition shall be the law of the country where competitive relations or the collective interests of consumers are, or are likely to be, affected.

2. Where an act of unfair competition affects exclusively the interests of a specific competitor, Article 4 shall apply.

3. (a) The law applicable to a non-contractual obligation arising out of a restriction of competition shall be the law of the country where the market is, or is likely to be, affected.

Where the market is, or is likely to be, affected in more than one country, the person seeking compensation for damage who sues in the court of the domicile of the defendant, may instead choose to base his or her claim on the law of the court seised, provided that the market in that Member State is amongst those directly

\footnotetext{
${ }^{107}$ Recital 19, Rome II Regulation.

${ }^{108}$ EU Commission, cited by Stone, note 93 supra, p.365 and Dickinson, note 36 supra, p.412.

${ }^{109}$ Recital 21, Rome II Regulation; Dickinson, note 36 supra, p.397.

${ }^{110}$ Recital 22, Rome II Regulation refers to the 'law of the country where the market is, or is likely to be, affected in more than one country ...' An approach endorsed by Withers, note 2 supra.

${ }^{111}$ Dickinson, note 36 supra, p.405.

112 Recital 21, Rome II Regulation.

${ }^{113}$ Dickinson, note 36 supra, p.397.

114 Recital 14, Rome II Regulation.

115 Words in bold for emphasis. Article 6(2) is not considered here.
} 
and substantially affected by the restriction in competition out of which the noncontractual obligation on which the claim is based arises; where the claimant sues, in accordance with the applicable rules on jurisdiction, more than one defendant in that court, he or she can only choose to base his or her claim on the law of that court if the restriction in competition on which the claim against each of these defendants relies directly and substantially affects also the market in the Member State of that court.

\section{The law applicable under this Article may not be derogated from by an agreement pursuant to Article 14. ${ }^{116}$}

Some of the key concepts of Article 6, namely 'unfair competition,' the 'affected market,' the effect on the market that justifies the application of Article 6(1) and the exception in Article 6(3), will now be considered. The lack of a clear definition of 'unfair competition' was acknowledged by the Wallis Report ${ }^{117}$ during the drafting process of the Regulation. ${ }^{118}$ Essentially, as the Commission and Dickinson have both observed, the conduct must affect more than one participant in the marketplace (vis. 'participants') or the 'derogation' ${ }^{119}$ in Article 6(2) will operate with the effect that the applicable law will instead be determined by Article $4 .{ }^{120}$ Whilst this may appear to provide a neat solution, the Commission acknowledged the lack of consistency in the connecting factors used in Articles 4 and $6 .{ }^{121}$ Nevertheless, Dickinson has helpfully suggested that for the purposes of Article 6, unfair competition under English law could encompass the torts of 'passing off, malicious falsehood [...] in comparative advertising, and actions by a non-public body [...] under Part 8 of the Enterprise Act $2002 \ldots{ }^{122}$ Of these, the first two could have a direct and detrimental impact upon consumers in the market.

Second, the objective of Article 6(1) is to protect claimants in the affected market. However a key criticism of the Regulation is that it does not provide a definition of the 'affected market' as a connecting factor. It is submitted that it given the scope of application of Article 6 - horizontal or vertical anti-competitive behaviour - a definition from the European Court of Justice could be helpful. If it was defined, it must first be done for the purposes of private international law. Furthermore, it may

\footnotetext{
${ }^{116}$ Article 6, Rome II Regulation. Words in bold for emphasis.

117 Stone, note 93 supra, p.366.

118 Dickinson, note 36 supra, p.403. Word italicised for emphasis.

${ }^{119}$ Dickinson, ibid, p.405. Words omitted for syntax.

${ }^{120}$ Dickinson, ibid, p.397.

${ }^{121}$ Ibid.

122 Dickinson, ibid, p.404.
} 
have to be distinguished depending on the direction of the behaviour in dispute. In response, Dickinson has explored the narrower and wider meanings that could be attributed to the 'affected market', namely a market restricted to a single country or area (used more generally in competition law) or a wider concept of affected market where claims can be brought either by competitors or consumers. ${ }^{123}$ Dickinson considers the potential application of a 'qualified affected market' ${ }^{124}$ approach to encompass not just competitors but also consumers and their collective representatives who have been affected by anti-competitive behaviour within $a$ particular area (as opposed to the entire marketplace). ${ }^{125}$ By that it is assumed that the damage must be attributable to consumers or their representatives in a particular territorial unit or jurisdiction, for it is the law of that place which will apply in a claim brought in the court of a Member State under Article 6. Support for this approach was illustrated by analogous rules in the Brussels I Regulation considered earlier. Third, the required 'effect' on the market must be sufficiently, or causally, material to justify the application of Article 6. Dickinson has suggested, in line with earlier authority from the Wood Pulp case, ${ }^{126}$ that the anti-competitive arrangement must have been 'implemented' within the Community, as opposed to quantifying a 'direct and sufficient effect' for the same purpose. Support for this view can also be drawn from Withers' analogy referred to earlier vis-a-vis distinguishing between the lex causae and the lex damni for the purposes of allocating jurisdiction for a cross-border tort. However the potential fragmentation of proceedings is increased as a result. Therefore, it must be shown that for Article 6 to apply anti-competitive behaviour and damage occurred in a particular territorial unit (jurisdiction) for the purposes of ascertaining the applicable law.

The applicable law rules for disputes as a result of a restriction of competition are contained in Article 6(3) and are deemed 'mutually exclusive' from the applicable law rules for unfair competition under Article 6(1). ${ }^{127}$ A restriction of competition is defined in Recital (23) as applying to

\footnotetext{
${ }^{123}$ Dickinson, ibid, p.413-414.

${ }^{124}$ Dickinson, ibid, p.414-415.

${ }^{125}$ Dickinson, ibid, p.414.

126 [1988] ECR 5193.

${ }^{127}$ Dickinson, ibid, p.418. On Article 6(3), see generally Fitchen, note 8 supra.
} 
prohibitions on agreements between undertakings, decisions by associations of undertakings and concerted practices which have as their object or effect the prevention, restriction or distortion of competition within a Member State or within the internal market, as well as prohibitions on the abuse of a dominant position within a Member State or within the internet market, where such agreements, decisions, concerted practices or abuses are prohibited by Articles 81 and 82 of the Treaty or by the law of a Member State. ${ }^{128}$

The implications of more than one applicable law applying as a result of Article 6(3) are apparent, particularly where more than one national market is or is likely to be affected by the restrictive behaviour. A key challenge of the Regulation will be to determine the 'affected market(s)' for the purposes of Article 6(3). As we have seen, the most effective starting point for the purposes of private international law is to determine the geographical location of the parties' activities in order to localise the dispute with a particular jurisdiction. Dickinson argues that whilst it may be necessary to consider a sub-category of connecting factors including, but not restricted to, such matters as national measures imposing barriers to trade, language and cultural differences, the views of market participants and differences in pricing, ${ }^{129}$ such a 'legal-economic analysis of this kind [...] is one of the least satisfactory aspects of the Rome II Regulation,' 130 and one that would probably have a prohibitive effect on litigation than facilitating predictability and certainty of result. In any event, an analogy with the European Commission's Statement on Article 15 and 73 of the Brussels I Regulation reminds us that language and currency were not deemed relevant considerations for the purposes of establishing whether a business directed its commercial activities towards a consumer's jurisdiction via a web site. However, perhaps Article 6(3) is simply concerned with distinguishing between disputes internal to each Member State, ${ }^{131}$ disputes where agreement or collusion regarding anti-competitive behaviour originated outside the EU but the behaviour itself occurred in a Member State and disputes between parties situated in different Member States. In any event, the ethos of choice of law rules is to ascertain the law of a territory which will then govern the dispute. Aside from determining the 'affected market' for

\footnotetext{
${ }^{128}$ Recital 23, Rome II Regulation. Words in bold for emphasis.

${ }^{129}$ Dickinson, ibid, p.422-423.

${ }^{130}$ Dickinson, ibid.

${ }^{131}$ Disputes between different parts of a Member State may still require reference to rules of private international law as they operate between those parts, eg. a dispute between parties situated in England and Scotland.
} 
the purposes of Article 6(3), it will also be necessary to determine the point in time when the restriction of competition occurred in the marketplace.

As an alternative to the law(s) of the affected market(s), the claimant can select the law of the forum (lex fori) under Article 6(3) provided that there is more than one country 'directly and substantially affected' by the implementation of the restrictive practice and the defendant is domiciled in the Member State of the lex fori. Whilst at first hand this escape clause might seem advantageous to a claimant, the absence of a clear definition of what constitutes a "direct and substantial" effect in the market of the lex fori could place an additional hurdle for the claimant to satisfy. A collective representative action on behalf of consumers could satisfy such a requirement. In any event the necessity for such a requirement is questioned given that if the claimant was to sue in the courts of the defendant's domicile under Article 2 of the Brussels I Regulation, the lex fori would apply. The defendant is already protected on the basis of actor sequitur forum rei, so the additional requirement appears unduly burdensome on a claimant.

\section{THE PROPOSAL FOR AN EU CONSUMER COLLECTIVE REDRESS MECHANISM}

In November 2008, the European Commission released a Green Paper on 'Consumer Collective Redress.' 132 The Green Paper outlines how the Commission seeks to consider 'options to close any gaps to effective redress' in both national and crossborder disputes with sellers especially when consumers are 'affected by the same legal infringement.' 133 According to Micklitz, Reich and Rott, the three bases for 'improv(ing) collective consumer protection is ...either ... internal market competence ... on Article 153(3)(b) in supporting Member States' measures ...[or]... the provisions of the Amsterdam Treaty on judicial cooperation in civil matters.' 134 As stated earlier, in accordance with Courage and Manfredi, the right to take action for breach of competition laws is permissible under Community law. Nevertheless, perhaps crucially, the 'procedural features, as well as the determination of the

\footnotetext{
132 EU Commission, 'Green Paper on Consumer Collective Redress', (COM 2008794 Final).

133 Green Paper, ibid, p.3, para.4.

${ }^{134}$ Micklitz, Reich, Rott, note 33 supra, p.351.
} 
competent court, are subject to national law.' 135 Accordingly, the precursor to effective private enforcement for breach of competition law rules is the ability of consumers to be able to collectively take action to via such a collective redress procedure facilitated by a Member State. When referring to collective redress, we are concerned here with an additional basis of private judicial redress by individuals and their representatives, not Alternative Dispute Resolution (ADR). ${ }^{136}$

The inherent 'success rate' of Article 6 of Rome II, as Fitchen remarks, will depend upon the 'interaction, in the text, of competing policies which have influenced the Commission's desire [for] reform of private enforcement...' ${ }^{137}$ As far as the EU Consumer Protection Policy is concerned, the requirement for Member States to provide 'effective proceedings' has existed for over three decades. ${ }^{138}$ As far as collective redress is concerned, Hodges has remarked that three key issues arise: (shared) competence, the capacity of representatives to take action and mutual recognition ${ }^{139}$ leading towards effective enforcement. In accordance with Article 4 TFEU, the EU only has competence to take measures for collective redress - as Hodges correctly asserts - if the 'objectives [have not or] cannot be sufficiently achieved by the Member States' ${ }^{140}$ (ie. subsidiarity) and 'measures at EU level must not go beyond what is necessary to achieve the objects at which they are directed [proportionality].' 141 Furthermore, in the context of cross-border disputes, the Member States' 'procedural autonomy' ${ }^{142}$ must also be respected, since Article 81 TFEU (ex Article 65 EC) 'requires evidence of cross-border matters and might ... justify only cross-border measures.' 143 In that regard, the current position of collective redress across the Member States is instructive. The legal basis as far as consumers are concerned is Article 115 TFEU (ex Article 95 EC) which requires

\footnotetext{
${ }^{135}$ Micklitz, Reich, Rott, ibid, p.337.

${ }^{136}$ Indeed, Micklitz Reich and Rott confirm in their opinion that the Community does not have competence in the area of ADR; ibid at p.342. As traditional and Communitarised private international laws provides rules for the determination of jurisdiction, choice of law and enforcement of foreign judgments, the use of ADR (however defined) as a means of facilitating collective consumer redress may be harder to justify.

${ }^{137}$ Fitchen, note 8, p.343.

${ }^{138}$ Micklitz, Reich, Rott, note 33 supra, p.342.

${ }^{139}$ C. Hodges, The Reform of Class and Representative Actions in European Legal Systems, (Hart, 2008), p.96.

${ }^{140}$ Hodges, ibid, p.93, 103 ; words in brackets added.

${ }^{141}$ Hodges, ibid.

142 Hodges, ibid.

${ }^{143}$ Hodges, ibid, p.94.
} 
consumers to be provided with a high level of protection. In accordance with Article 4 TFEU, the continued sharing of competence in the field of consumer protection will heavily impact upon any EU-wide collective redress mechanism. ${ }^{144}$ A recent paper by Fairgreave and Howells highlights the inherent challenges posed by shared competence. These authors suggest that "national reform' ${ }^{\prime 45}$ is the most likely outcome for claims already viable under national law. Alternatively, at best the mechanism could facilitate the resolution of otherwise "non-viable consumer claims $^{146}$ such as claims for damages for anti-competitive behaviour. Provided the Community has competence to instigate and enforce consumer collective redress in respect of the latter claims, the proposal would be a first, in that it would extend the principle of subsidiarity by providing the first cross-border basis for implementing, or enforcing, ${ }^{147}$ collective redress via the Rome II Regulation. As far as consumer law is concerned, Directives have traditionally facilitated consumer collective redress mechanisms by permitting Member States to implement such measures over and above the minimum required by EU law. The legal basis that a future collective redress mechanism will take (whether a Regulation or Directive) and its remit (that is, depending on the viability of the claim) are both crucial to achieving the objective of mutual recognition. If implemented as a Regulation, and in combination with the "maximisation" of consumer protection policy, such a collective redress mechanism would complement existing national collective redress procedures where they exist. A Directive would not meet the objectives of maximising consumer protection across the Community.

The Green Paper considered four options for the development of collective redress at Community level; no action; cooperation between the Member States; a mix of policy instruments with a heavy reliance on ADR; and judicial collective redress. The first has been dismissed as it would not meet Treaty obligations in ensuring consumers are provided with maximum protection. The second option is also not being pursued as the cooperation mechanism required between the Member States could be at odds with existing national measures and, in any event, top-down regulation would still be required. The third option has also been excluded, primarily because of the infancy of

\footnotetext{
${ }^{144}$ See generally Fairgreave and Howells, note 2 supra.

${ }^{145}$ Fairgreave and Howells, ibid, p.379.

${ }^{146}$ Fairgreave and Howells, ibid.

${ }^{147}$ Hodges, note 139 supra, p.103.
} 
ADR and wider issues of competence. ${ }^{148}$ Accordingly, the current status of the proposal for an EU Collective Redress Mechanism has taken the fourth option, specifically a test case procedure in one Member State (ie by a consumer representative) followed up by individual action in other Member States. In practice, as currently proposed, it could be possible for consumer representatives to sue via a test case procedure the offending business where the defendant is located (Article 2, Brussels I) in order that a claim for all of the damage (Article 6(1), Rome II) could be sought. Thereafter, consumers could sue in any of the places where damage occurred by virtue of Article 5(3) of Brussels I, thereby enabling the law of that place to apply in accordance with Article 6(1) of Rome II.

\section{CONCLUSION}

In 2002 Withers remarked that

(I)t remains uncertain whether the requisite elements (both procedural and substantive) of a claim for breach of Community competition rules are destined to be determined by Community law, rather than national law. ${ }^{149}$

This paper has sought to briefly explore some of the issues raised by the specific applicable law rules for unfair competition and acts restricting free competition in the new Rome II Regulation on non-contractual obligations. Although the rules are drafted in such terms as to ensure that commercial entities and final end-user/private consumers (or their representatives) can claim damages for anti-competitive behaviour or an act restricting competition, a number of key concepts under Article 6 have not been sufficiently defined. Until such time that judicial guidance is provided by the ECJ, Article 6 will present challenges for private litigants who seek to utilise the EU's efforts to communitarise conflict of laws rules for anti-competitive behaviour and acts restricting competition. Furthermore, a key strength of Article 6 of Rome II is the ability of consumer representatives to claim damages on behalf of consumers. As far as Article 6 of the Rome II Regulation is concerned, the proposed EU Consumer Collective Redress mechanism must therefore seek to address what Hodges identifies as the 'real issue' vis-à-vis effective collective redress namely,

\footnotetext{
148 See Micklitz, Reich and Rott, note 33 supra.

${ }^{149}$ Withers, note 2 ibid, p. 253.
} 
first $[\ldots]$ to deliver rectification of market imbalances: secondly, to deliver compensation when due; thirdly, [control] behaviour and; and fourthly, to enhance the economy. ${ }^{150}$

${ }^{150}$ Hodges, note 139 supra, p.248. Word added for syntax. 